\title{
Comparative Evaluation of the Growth Performance and Feed Intake of Weaned Rabbits Fed Tropical Grasses and Selected Forage Leaves
}

\author{
Amata, I.A, E.O. Okorodudu \\ Department of Animal Science, Delta State University, Asaba Campus
}

\begin{abstract}
Twenty weaned chinchilla rabbits of mixed sexes aged between 8 to 9 weeks were randomly allotted to five different dietary treatments with four rabbits per treatment. Each rabbit was used as a replicate. Three tropical grasses and leaves from two forage plants were used to prepare the test diets. The leaves were obtained from Myrianthus arboreus and Gmelina arborea; two common forages and the tropical grasses used include; Tridax procumbens, Pannicum maximum and Pennisetum purpureum. Parameters studied include average weekly feed intake, average weekly weight gain, feed conversion ratio and feed efficiency ratio. The study was carried out in the rabbit section of the Faculty of Agriculture Research and Teaching Farm of the Delta State University Asaba Campus, Delta State Nigeria, located at $6^{0} 14^{\prime} \mathrm{N}$ and $6^{\circ} 49^{\prime} \mathrm{E}$. The forages were fed with a concentrate diet separately and the feeding ratio used was 2:1. Significance was reported at 5\% level of probability and the means were separated using Duncan's Multiple Range Test Procedure. Significant $(P<0.05)$ differences were observed for all parameters measured between all the test materials. Variations in average feed intake and average weight gain were observed and values obtained were within the ranges of reported values.
\end{abstract}

Keywords: Weaned rabbits, forage leaves, tropical grasses, feed intake, weight gain, feed efficiency ratio, feed conversion ratio.

\section{INTRODUCTION}

The rapid increase in the World population in general and in Nigeria in particular has aggravated animal protein deficiency. F.A.O (2006) estimated the average animal protein consumption in Nigeria to be $7.4 \mathrm{~g}$ per capita/day as compared to $38 \mathrm{~g}$ per capita/day of animal protein consumed in South Africa. The increasing demand for animal protein shows the need to intensify livestock production.

One of the solutions to the problem of protein shortage in the diet of most Nigerians is the rearing of rabbits at both subsistence and commercial levels. Rabbits play an important role in the supply of animal protein to the Nigerian populace (Amaefule et al., 2005) and they possess a number of features that are of advantage which include high growth rate, high efficiency in converting forage to meat, short gestation period and high prolificacy, relatively low cost of production and high nutritional quality of rabbit meat (Biobaku and Oguntona, 1977). However the high cost of conventional feed for production of livestock makes it expensive for consumers (Akinmutimi and Ezea, 2006).

The beneficial effects of feeding rabbits with notable concentrate and forage rations has been widely discussed (Dematerova et al., 1991; Nwogu et al., 1999). Forages such as Panicum maximum (guinea grass), Pennisetum purpureum (elephant grass), Tridax procumbens are acceptable by rabbits (Abu et al., 2008). Studies have been carried out by various researchers (Raharjo et al., 1988; Ukpe et al., 2009; Nwagu et al., 2010) on the use of legumes as feeding materials and have shown positive results.

Rabbits diets consists largely of forages and are referred to as pseudo-ruminants, however their ability to digest feed depends on the nutrient composition of the diet (Lebas et al., 1986). A range between 12 and 22\% protein has been suggested by several authors (Davidson and Spreadbury, 1975; Omole, 1982). A significant positive correlation exists between the protein content of the feed and the crude protein digestibility (Feteke and Gippert, 1986). Studies have shown that a 50:50 mixture of Centrocema pubescens and a maize concentrate diet is optimal for maximum performance (Nworgu et 
$a l$, 1999). Optimal performance of weaner rabbits fed a mixture of legumes and a maize concentrate diet has been attributed to the high content of digestible protein and energy content of the diet.

This study was carried to compare the effect of feeding weaned rabbits with three common tropical grasses; Tridax procumbens, Pannicum maximum and Pennisetum purpureum and the leaves of two forage plants; Myrianthus arboreus and Gmelina arborea, on the growth performance of the test animals. Parameters looked at include average weekly feed intake, average weekly weight gain, feed conversion ratio and feed efficiency ratio. The choice of the test materials is as a result of studies on the nutrient composition of the selected test materials (Amata, 2010 ; Amata and Lebari, 2011).

\section{Materials ANd Methods}

This study was conducted in the rabbit unit of the Delta State University Research and Teaching Farm, Asaba Campus, Delta State Nigeria ( $6^{\circ} 14^{\prime} \mathrm{N}$ and $\left.6^{\circ} 49^{\prime} \mathrm{E}\right)$.

\section{Test Materials and Diets}

Fresh young leaves of Tridax procumbens, Pannicum maximum, Pennisetum purpureum, Myrianthus arboreus and Gmelina arborea, were collected from the farm lands within the university community and fed with normal concentrate diets.

The composition of the concentrate diet is given in Table 1 below. The diet was formulated to contain approximately 21 per cent crude protein and $2340 \mathrm{kcal} / \mathrm{kg}$ metabolizable energy.

Table1. Composition of concentrate diet ( $\mathrm{g} / \mathrm{kg} \mathrm{DM})$

\begin{tabular}{|c|c|}
\hline Maize & 54 \\
\hline Soya Beans & 17 \\
\hline Fish Meal & 4 \\
\hline Wheat Offal & 20 \\
\hline Bone Meal & 2.2 \\
\hline Salt & 1 \\
\hline Premix & 1 \\
\hline Methionine & 0.4 \\
\hline Lysine & 0.4 \\
\hline Calculated Crude Protein & $21 \%$ \\
\hline
\end{tabular}

The experimental diets were prepared as given below

Treatment 1 (T1 control); Concentrate diet + Tridax procumbens,

Treatment 2 (T2): Concentrate diet + Panicum maximum,

Treatment 3 (T3): Concentrate diet + Pennisetum purpureum,

Treatment 4 (T4): Concentrate diet + Myrianthus arboreus

Treatment 5(T5): Concentrate + Gmelina arborea.

Tridax procumbens was chosen as the control diet because recent studies (Bello et al., 2001; Mmereole et al., 2011; Singh et al., 2007) have shown positive growth and production performances by rabbits fed diets with Tridax procumbens.

\section{ANimals AND THEIR Management}

Twenty weaned chinchilla rabbits of mixed sexes aged between 8 to 9 weeks were weighed individually and randomly assigned to the five experimental diets with four rabbits per treatment. Each rabbit was used as a replicate. The rabbits were housed singly in hutches. On arrival, the rabbits were given anti- stress drugs and multivitamins. The hutches, drinking and feeding equipment were cleaned daily. Weighed amounts of the experimental diets were given to the animals for a period of five weeks. Concentrate and forage were fed separately in a ratio of 1:2.

\section{Experimental Procedure}

Proximate analysis was carried out to determine the proximate composition of the forage using AOAC (1990) methods. Measurements of the average weekly feed intake and average weekly weight gain were carried out. Values obtained were used to calculate feed conversion ratio and feed efficiency ratio.

\section{Statistical Analysis}

Data collected were subjected to a one-way analysis of variance (ANOVA) procedure in a completely randomized design, using the IRRISTAT for windows (version 5.0) computer software. 
Duncan's Multiple Range Test (Duncan, 1955) was used to separate the means at 5\% level of probability.

\section{RESULTS AND DISCUSSION}

The results of the proximate analysis of the test forages given to the experimental animals are given in Table 2 below. Significant differences $(\mathrm{P}<0.05)$ exist between the means of the test forages. Moisture content of Tridax procumbens is significantly higher than the other test materials. Myrianthus arboreus has significantly $(\mathrm{P}<0.05)$ higher ash content than the other test materials indicating high mineral content.. Gmelina arborea has significantly $(\mathrm{P}<0.05)$ higher ether extract values indicating a higher fat content. Pannicum maximum has significantly higher crude fiber values than the other test materials except Pennisetum purpureum. Crude fiber is useful for maintaining bulk motility and increased intestinal peristalsis by surface extension of the food in the intestinal tract (Mathenge, 1997). It is also necessary for food digestion. The results show that the crude fiber content of all the test materials are within the ranges of reported values and are therefore suitable as feed materials for animals. Crude protein values are lower for the grasses compared with the leaves of the forage plants. Values for crude protein of the leaves of the forage plants fall within the range of reported values (Amata, 2010) and are significantly higher in M. arboreus than the other test materials.

Table2. Proximate Composition of the forages (\%)

\begin{tabular}{|c|c|c|c|c|c|}
\hline & Moisture & Ash & Ether Extract & Crude Fiber & Crude Protein \\
\hline T. procumbens (T1) & $2.05^{\mathrm{a}}$ & $9.65^{b}$ & $4.25^{\mathrm{b}}$ & $30.40^{\mathrm{b}}$ & $1.31^{\mathrm{c}}$ \\
\hline P. maximum (T2) & $1.23^{\mathrm{b}}$ & $2.12^{\mathrm{c}}$ & $1.45^{\mathrm{c}}$ & $39.65^{\mathrm{a}}$ & $0.88^{\mathrm{d}}$ \\
\hline P.purpureum (T3) & $1.10^{\mathrm{c}}$ & $6.11^{\mathrm{c}}$ & $2.61^{\mathrm{c}}$ & $38.81^{\mathrm{a}}$ & $0.95^{\mathrm{d}}$ \\
\hline M. arboreus & $1.25^{\mathrm{b}}$ & $13.05^{\mathrm{a}}$ & $1.82^{\mathrm{d}}$ & $27.35^{\mathrm{bc}}$ & $18.0^{\mathrm{a}}$ \\
\hline G. arborea & $2.00^{\mathrm{a}}$ & $4.24^{\mathrm{d}}$ & $5.25^{\mathrm{a}}$ & $24.25^{\mathrm{c}}$ & $14.6^{b}$ \\
\hline
\end{tabular}

a,b,c Means with different superscript within the same column are significantly $(\mathrm{P}<0.05)$ different

Results for the average weekly intake of the test diets are given in Table 3 below. The results show significant $(\mathrm{P}<0.05)$ differences between the test diets in the first week of the experiment. Intake was significantly $(\mathrm{P}<0.05)$ higher with rabbits fed diet $\mathrm{Tl}$, followed by rabbits fed diet $\mathrm{T} 3$. Lowest intake was recorded by rabbits fed diet T5. Several authors (Aderinola et al., 2008; Mmreole et al., 2011) have revealed improved growth performances with rabbits fed maize with tropical grasses such as Tridax procumbens and Centrosema pubescens. Results obtained in week 2 followed the same trend with the feed intake increasing. Results in week 3 indicate that feed intake by rabbits fed diets $\mathrm{Tl}$ and $\mathrm{T} 3$ were the same with the feed intake by these two groups being significantly $(\mathrm{P}<0.05)$ higher than the other groups. Significantly $(\mathrm{P}<0.05)$ lower values were recorded for the leaves of the two forage plants, Myrianthus arboreus and Gmelina arborea. It has been shown (Mmereole et al., 2011; Nworgu et al., 1999; Singh et al., 2007), that rabbits perform better when fed rations mixed with grass. Results in week 3 also show that feed intake reaches a peak with rabbits fed diets T4 and T5 and reduces in weeks 4 and 5. In weeks 4and5 results show that rabbits fed diets $\mathrm{Tl}$ and $\mathrm{T} 3$ showed significantly $(\mathrm{P}<0.05)$ higher feed intake than diets $\mathrm{T} 2$, T4 and $\mathrm{T} 5$.

Table 3. Average weekly feeds intake of rabbits fed the experimental diets

\begin{tabular}{|c|c|c|c|c|c|}
\hline & Week 1 & Week 2 & Week 3 & Week 4 & Week 5 \\
\hline T. procumbens $(\mathrm{T1})$ & $1.45^{\mathrm{a}}$ & $1.48^{\mathrm{a}}$ & $1.62^{\mathrm{a}}$ & $1.65^{\mathrm{a}}$ & $1.66^{\mathrm{b}}$ \\
\hline P.maximum (T2) & $0.89^{c}$ & $0.98^{\mathrm{c}}$ & $1.23^{\mathrm{c}}$ & $1.36^{\mathrm{b}}$ & $1.39^{\mathrm{c}}$ \\
\hline P.purpureum (T3) & $1.39^{b}$ & $1.42^{b}$ & $1.63^{\mathrm{a}}$ & $1.65^{\mathrm{a}}$ & $1.69^{\mathrm{a}}$ \\
\hline M.arboreus (T4) & $0.69^{\mathrm{d}}$ & $0.73^{\mathrm{d}}$ & $0.84^{\mathrm{d}}$ & $0.82^{\mathrm{c}}$ & $0.78^{d}$ \\
\hline G.arborea & $0.41^{\mathrm{c}}$ & $0.43^{\mathrm{c}}$ & $0.79^{c}$ & $0.81^{\mathrm{c}}$ & $0.68^{\mathrm{d}}$ \\
\hline
\end{tabular}

${ }_{\mathrm{a}, \mathrm{b}, \mathrm{c}}$ Means with different superscripts within the same column are significantly $(\mathrm{P}<0.05)$ different

The results for the weekly weight gain of the test animals are given in Table 4 below. Results show significant $(\mathrm{P}<0.05)$ differences between the average weekly weight gains of the experimental animals. In week 1 rabbits fed diets $\mathrm{Tl}, \mathrm{T} 2$ and $\mathrm{T} 3$ had significantly $(\mathrm{P}<0.05)$ higher weight gain values than rabbits fed diets $\mathrm{T} 4$ and $\mathrm{T} 5$, with rabbits fed diet $\mathrm{Tl}$ (control) having the highest weight gain values. In week 2 the results showed the same weight gain values as in week 1 . In week 3 results obtained revealed significant $(\mathrm{P}<0.05)$ differences between the average weekly weight gain values of the experimental animals. Rabbits fed diet 1 had the highest values and those fed diet T5 had the 
lowest values. In weeks 4 and 5, further weight gains were not recorded for animals fed diet T4. Rabbits on diet T5 recorded a drop in weight gain. The highest weight gain values in week 5 were observed for rabbits fed diets $\mathrm{Tl}$ and T3. Weekly weight gains were recorded in the first three weeks for all the rabbits fed the experimental diets

Table 4. Average weekly weight gain of rabbits fed the test diets

\begin{tabular}{|c|c|c|c|c|c|}
\hline Diet & Week 1 & Week 2 & Week3 & Week 4 & Week 5 \\
\hline T1 & $0.4^{\mathrm{a}}$ & $0.8^{\mathrm{a}}$ & $1.0^{\mathrm{a}}$ & $1.2^{\mathrm{a}}$ & $1.4^{\mathrm{a}}$ \\
\hline T2 & $0.3^{\mathrm{b}}$ & $0.6^{\mathrm{b}}$ & $0.9^{\mathrm{b}}$ & $1.2^{\mathrm{a}}$ & $1.3^{\mathrm{b}}$ \\
\hline T3 & $0.3^{\mathrm{b}}$ & $0.6^{\mathrm{b}}$ & $1.0^{\mathrm{a}}$ & $1.2^{\mathrm{a}}$ & $0.9^{\mathrm{b}}$ \\
\hline T4 & $0.2^{\mathrm{c}}$ & $0.5^{\mathrm{c}}$ & $0.9^{\mathrm{b}}$ & $0.9^{\mathrm{b}}$ & $0.8^{\mathrm{c}}$ \\
\hline T5 & $0.2^{\mathrm{c}}$ & $0.4^{\mathrm{c}}$ & $0.8^{\mathrm{c}}$ & $0.9^{\mathrm{c}}$ & $^{\mathrm{c}}$ \\
\hline
\end{tabular}

a,b,c Means with different superscripts within column are significantly $(\mathrm{P}<0.05)$ different.

Table 5 below shows the results for feed conversion ratio. Results obtained revealed significant $(\mathrm{P}<0.05)$ differences between the means. Feed conversion in week 1 was significantly $(\mathrm{P}<0.05)$ higher with rabbits fed diet T3, lowest feed conversion ratio was recorded by rabbits fed diet T5. In week 2 , results obtained showed a drop in the feed conversion ratios, with rabbits fed diets $\mathrm{Tl}$ and $\mathrm{T} 3$ having significantly $(\mathrm{P}<0.05)$ higher values than rabbits fed the other test diets. The same trend was observed throughout the experimental period with rabbits fed diets $\mathrm{Tl}$ and $\mathrm{T} 3$ recording higher feed conversion ratios while rabbits fed diets $\mathrm{T} 4$ and $\mathrm{T} 5$ recorded the lowest feed conversion ratios towards the later part of the experimental period. Feed conversion ratios show how much weight the animal gains per kilogram of feed. Lower feed conversion ratios indicate efficient users of feed (Lebas et al., 1986). The feed conversion ratio of rabbits fed diets $\mathrm{T} 4$ and $\mathrm{T} 5$ show lower feed conversion ratios, and these values decreased throughout the experimental period

Table 5. Weekly feed conversion ratio of rabbits fed the experimental diets

\begin{tabular}{|l|c|c|c|c|c|}
\hline Diet & Week 1 & Week 2 & Week 3 & Week 4 & Week 5 \\
\hline T1 & $3.63^{\mathrm{b}}$ & $1.85^{\mathrm{b}}$ & $1.62^{\mathrm{a}}$ & $1.38^{\mathrm{a}}$ & $1.20^{\mathrm{a}}$ \\
\hline T2 & $2.97^{\mathrm{d}}$ & $1.63^{\mathrm{c}}$ & $1.37^{\mathrm{b}}$ & $1.13^{\mathrm{c}}$ & $1.10^{\mathrm{b}}$ \\
\hline T3 & $4.63^{\mathrm{a}}$ & $2.40^{\mathrm{a}}$ & $1.63^{\mathrm{a}}$ & $1.38^{\mathrm{b}}$ & $0.87^{\mathrm{c}}$ \\
\hline T4 & $3.45^{\mathrm{c}}$ & $1.46^{\mathrm{d}}$ & $0.93^{\mathrm{c}}$ & $0.91^{\mathrm{d}}$ & $0.85^{\mathrm{c}}$ \\
\hline T5 & $2.05^{\mathrm{c}}$ & $1.08^{\mathrm{c}}$ & $0.99^{\mathrm{c}}$ & $0.90^{\mathrm{d}}$ & $0.005)$ \\
\hline
\end{tabular}

a,b,c Means with different superscripts within columns are significantly $(\mathrm{P}<0.05)$ different.

\section{Conclusion}

The results of the experiment reveal that feed intake was higher with rabbits fed diets Tl and T3 also results for weight gain also showed that rabbits fed diets T1, T2 and T3 performed better. Growth performance is better appreciated when feed conversion and feed efficiency ratios are considered. These indices show how much weight the animals gain per kilogram of feed consumed. Animals with a lower feed conversion ratio and higher feed efficiency ratio are considered efficient feed users.

Results obtained show that rabbits fed diets T4 and T5 efficiently used the feed given more than rabbits fed diets $\mathrm{Tl}, \mathrm{T} 2$ and T3. Results obtained would therefore suggest that rabbits do better when fed the leaves of browse plants and concentrate when compared to rabbits fed tropical grass with concentrate.

\section{REFERENCES}

[1] Abu, O.A., Onifade, A.A., Abanikanda, O.T.F and Obiyan, R.I (2008). Status and promotional strategies for rabbit production in Nigeria. Management and Economy $9^{\text {th }}$ World Rabbit Congress. Verona-Italy.

[2] Aderinola, O.A, Ojebiyi. O.O., Rafiu, T.A, Akinlade, J.A, Adepoju, L.O (2008). Performance evaluation of growing rabbits fed diets containing varving inclusion levels of Centrocema pubescens or CalaDogonium mucunoides in the Savannah Zone of Nigeria. Nutrition and Digestive Physiology, $9^{h}$ World Rabbit Conference. Pp 525-528

[3] Akinmutimi, A.H. and Ezea,J. (2006). Effect of graded levels of toasted lima beans (Phaseolus lunatus) meal on weaner rabbit diets. Pakistan Journal of Nutrition 5:368-372.

[4] Amaefule, K.U., Iheukwuemere, F.C. and C.C. Nwaokoro (2005). A note on the growth 
performance and carcass characteristics of rabbits fed graded dietary levels of boiled pigeon pea seed (Cajanus cajan). Livestock Res. Rural Dev., 17:1-6.

[5] Amata, I.A. (2010) Nutritive value of the leaves of Myrianthus arboreus: A browse plant. International Journal of Agricultural Research. 5(8):576-581

[6] Amata, I.A. and Lebari, T.A. (2011). Comparative evaluation of the nutrient profile of four selected browse plants in the tropics, recommended for use as non-conventional livestock feeding materials. African Journal of Biotechnology, 10 (64): 14230-14233.

[7] AO AC (1990) Official methods of analysis $15^{\text {th }}$ ed, Association of Official Analytical Chemists, Washington DC Arlinton, VA, Pp 503-515

[8] Bello,K.M., Oyawoye, E.O. and Adegbola. T.A. (2001). Performance of weaner rabbits fed varying levels of Tridax procumbens. Nigerian Journal of Animal Science. 4(2)

[9] Biobaku, W.O. and Oguntona, E.B. (1977). The effects of feeding multi nutrient mini blocks and pelleted diets on the growth of rabbits. Nigerian Journal of Animal Production, 24:147-149.

[10] Davidson, J and Spreadbury, D (1975). Tropical Feeds, feed information summaries and nutritive values, FAO. Rabbit production and health series. Pp78

[11] Dematerova. M. Periera, C.L and Dabe, A.C. (1991). Effect of feeding Gliricidia sepium meal on the performance of white leghorn chicks. Animal Science. 12:47-63.

[12] Duncan, D.B (1955). Multiple range and F tests biometrics, 25-40

[13] F.A.O, (2006) Food and Agricultural Organization Statistical Data Base. Rome Italy pp: 234236.

[14] Feteke, S and Gippert, A. (1986). Effect of age, sex and time of bleeding on the hematological characteristics of guinea fowl. Nigerian Jornalo of Animal production. 13:93-101

[15] Mathenge,L (1997) Nutrition value and utilization of indigenous vegetables in Kenya. In IPGRI International workshop on genetic resources of traditional vegetables in Africa. Conservation and use, KRAF-HQ, Nairobi, Institute of plant genetics and crop plant research, Rome: 76-77.

[16] Mmereole, F.U.C., Egoh, J.O. and Obinne, J.I. (2011). Growth performance and cost analysis of weaner rabbits fed varying dietary levels of crude protein supplements with Tridax procumbens. Pakistan journal of Nutrition. 10(2): 120-123

[17] Nworgu, F.C. Olupona, J.A., Olukoya, J.A and Bamgbose, A.M.(1999) Principles and procedure of statistics. A Biochem approach $2^{\text {nd }}$ edition McGraw-Hill Kogakwha Ltd, Tokyo

[18] Omole, J.A. (1982). The effect of graded levels of dietary protein on growth and reproductive performance of rabbits. J. Applied Rabbit Research. 5:83-88.

[19] Singh, D.A.D., Kumar, P and Saravanakumar, V. R. (2007). Production performance of white giant rabbits fed with Tridax procumbens. Indian Veterinary Journal, 84(11): 1212-1213. 